\title{
EFFECT OF CULTIVARS, SOME CLIMATIC FACTORS AND PLANT DEVELOPMENTAL STAGES ON THE POPULATION DENSITY OF ONION THRIPS, THRIPS TABACI LIND. ON GARLIC PLANTS IN EGYPT
}

\author{
Hussein, S.H.A.; Hanafy, A.R.I. and Maha, A.M. Tantawy. \\ Plant Protection Research Institute, (A.R.C), Giza.
}

\begin{abstract}
This study was carried out in Beni-Suef district to study the effect of cultivars, some climatic factors and plant age on the population density of Thrips tabaci Lind. on two recommended garlic cultivars, Balady and Chinese throughout two successive seasons 2006-2007 and 2007-2008.

The results revealed that the highest infestation rate of $T$. tabaci was recorded on Balady cultivar, as the corresponding mean number of nymphs and adults were 82.94 and 11.12 individuals / plant in the first season and 62.91 \& 11.71 individuals / plant in the second season, respectively. The lowest mean number of $T$. tabaci was recorded during first period and increased gradually to reach the maximum number during the second period. Positive relationships were recorded between the population density of $T$. tabaci and the developmental stages of plant. The population density of T. tabaci nymphs and adults were negatively correlated with maximum and minimum temperatures. On the other hand, the mean of R.H was affected positively on the population of $T$. tabaci in the two investigated years. In the first season, climatic factors were more effective on T. tabaci population nymphs and adults, as the CD (Correlation Coefficient of Determination) were 68.55 and $78.97 \%$ for nymphs and adults on Balady cultivar and vies versa in the second season.
\end{abstract}

Key words: Cultivars, Climatic factors, Population density, Plant developmental stages, Thrips tabaci Lind, Garlic.

\section{INTRODUCTION}

Garlic, Allium sativum L., is the most economic crop, was grown and consumed in Egypt and other Mediterranean regions, as early as 3000 B.C., as reported by Tindall (1983) and Yamagucchi (1983).

In Egypt, garlic is extensively grown for both local consumption and exportation to the foreign countries viz., fresh materials, frozen paste, dried powder and extracted oil (Sakr, 1996). The planting area of garlic production in Egypt was estimated as 186396 feddan in 2006, which produced 3904976 tons with an average 20.950 tons per feddan.

The onion thrips, Thrips tabaci Lind.is known as a major pest of cotton seedlings, onion and some vegetable crops in Egypt (Hamdy and Salem 1994). This insect sucks the plant sap causing a considerable damage of the garlic yield production (Daiber 1996 and Duchovskiene 2006). In addition to the direct impacts, onion thrips is an efficient vector for iris yellow spot virus, a potentially destructive disease in onion. Thrips feeding also predisposes onion plants to invasion by the fungal pathogen Alternaria porri, which causes the disease purple blotch Mo et al., 2009. Thrips tabaci individuals transmit

Fayoum J. Agric. Res. \& Dev., Vol.24, No.1, January, 2010 
the tomato spotted wilt disease to several crops (Vierbergen 1990). Therefore, the aim of the present study is to evaluate the effect of cultivars, climatic factors (daily maximum and minimum temperature and mean of relative humidity) and plant age on the population dynamics of this insect on the two garlic cultivars, Balady and Chinese.

\section{MATERIAL AND METHODS}

Field experiments were carried out in Beni-Suef district to study the effect of cultivars, climatic factors and plant age on the population density of Thrips tabaci Lind. infesting two recommended garlic cultivars, Balady and Chinese throughout two successive seasons 2006-2007 and 2007-2008.

The chosen area was about 0.25 feddan $\left(1050 \mathrm{~m}^{2}\right)$.the whole area was divided into 8 plots. Each plot was about $131.25 \mathrm{~m}^{2}$. Each cultivar of garlic was planted randomly in four plots. All plots were arranged in a Randomized Complete Block design in three replicates.

All plots received the normally recommended agricultural practices for garlic cultivation except for the absence of any pesticides application.

Through two season studies, garlic seedlings of two cultivars were transplanted at October, $15^{\text {th }}$. Sampling of garlic plants started 20 days after broadcasting and continued every 10 days intervals. 10 plants were picked randomly and kept in a tight closed paper to be transfer to laboratory to inspect by stereomicroscope to determine T.tabaci individuals (nymphs+ adults) which were counted and recorded. The comparison between mean numbers of thrips on the two tested garlic cultivars were statistically and some climatic factors (the mean daily time (maximum) and night (minimum) temperatures and the mean relative humidity) and development stages of plant ages (first from transplanting till 60 days later, the second from 60 to 120 days and third one from 120 to harvesting were also recorded to determine the relationship between these two factors and infestation of T.tabaci on two studied cultivars.

The simple correlation and partial regression were adapted to show the average rate of changes in insect population due to change in the two climatic factors. Data were analyzed according to SAS program (1988). Mean separation was conducted by using Duncan's multiple range test in the same program.

\section{RESULTS AND DISCUSSION}

1: Effect of two garlic cultivars on the population density of Thrips tabaci.

Data in Table (1) show that the Badly cultivar habourd the highest mean numbers of T.tabaci nymphs and adults than Chinese cultivar in the two season studies. In the first season $2006-2007$, the seasonal mean numbers of T.tabaci were 82.94 and 63.10 nymphs/ plant and $11.12 \& 7.94$ adults /plant for the two tested cultivars, respectively.

The corresponding numbers that were counted in the subsequent season estimated $62.91 \& 40.93$ nymphs / plant and $11.71 \& 5.79$ adults/plant for Balady and Chinese cultivars, respectively.

The differences between means of the two cultivars were always significant in the investigated season.

It is clear from the same Table (1) that the infestation of garlic plant with T.tabaci nymphs and adults started with few numbers at the beginning of the two studied seasons, and then the counted mean numbers increased amongst the successive samples. The highest numbers of nymphs were detected in the $13^{\text {th }}$ of February during the first season, 241.90 and 185.70

Fayoum J. Agric. Res. \& Dev., Vol.24, No.1, January, 2010 
EFFECT OF CULTIVARS, SOME CLIMATIC FACTORS.

nymphs /plant for Balady and Chinese cultivars, respectively and $4^{\text {th }}$ of March during the second season (232.00 and 191.40 nymphs /plant for two cultivars, respectively. While the heaviest infestation of adults recorded in the $13^{\text {th }}$ of February and $24^{\text {th }}$ of January in the first season (31.60 and 35.70 adults /plant) for the two inspected cultivars, respectively and during $13^{\text {th }}$ of February (28.20 and 13.60 adults /plant) for the two inspected cultivars during the second season.

As for the liability of garlic cultivars to infestation with T. tabaci nymphs and adults, Balady cultivar appeared as, significantly, more susceptibility than Chinese cultivar (Table 1).

Table (1): Mean numbers of onion thrips, Thrips tabaci nymphs and adults on the two garlic cultivars throughout two successive seasons, 2006-2007 and 2007-2008 at Beni-Suef district.

\begin{tabular}{|c|c|c|c|c|c|c|c|c|}
\hline \multirow{3}{*}{$\begin{array}{c}\text { Inspection } \\
\text { dates }\end{array}$} & \multicolumn{4}{|c|}{ 2006-2007 season } & \multicolumn{4}{|c|}{ 2007-2008 season } \\
\hline & \multicolumn{2}{|c|}{ Nymphs/plant } & \multicolumn{2}{|c|}{ Adults/ plant } & \multicolumn{2}{|c|}{ Nymphs/ plant } & \multicolumn{2}{|c|}{ Adults/plant } \\
\hline & Balady & Chinese & Balady & Chinese & Balady & Chinese & Balady & Chinese \\
\hline N0v., $5^{\text {th }}$ & 0.70 & 0.00 & 0.40 & 0.60 & 1.10 & 0.20 & 0.80 & 0.10 \\
\hline $15^{\text {th }}$ & 6.00 & 5.00 & 0.80 & 1.20 & 2.80 & 0.60 & 1.50 & 0.20 \\
\hline $25^{\text {th }}$ & 8.80 & 6.70 & 3.90 & 2.40 & 4.20 & 5.80 & 2.20 & 0.40 \\
\hline Dec.,5 & 12.10 & 15.40 & 9.30 & 3.70 & 9.60 & 7.60 & 3.10 & 1.90 \\
\hline $15^{\text {th }}$ & 48.50 & 31.30 & 11.80 & 11.60 & 14.20 & 10.00 & 4.40 & 3.60 \\
\hline $25^{\text {th }}$ & 69.40 & 50.30 & 10.70 & 7.60 & 37.80 & 32.20 & 11.80 & 5.20 \\
\hline Jan., $4^{\text {th }}$ & 127.30 & 90.40 & 16.00 & 12.80 & 43.20 & 36.80 & 9.40 & 6.40 \\
\hline $14^{\text {th }}$ & 125.70 & 106.30 & 20.50 & 16.60 & 35.20 & 29.80 & 8.20 & 5.70 \\
\hline $24^{\text {th }}$ & 158.90 & 147.40 & 17.70 & 35.70 & 54.40 & 27.20 & 15.20 & 12.20 \\
\hline Feb., $3^{\text {rd }}$ & 106.90 & 77.40 & 22.80 & 9.00 & 71.80 & 69.20 & 18.40 & 10.00 \\
\hline $13^{\text {th }}$ & 241.90 & 185.70 & 31.60 & 15.30 & 110.80 & 84.00 & 28.20 & 13.60 \\
\hline $23^{\text {rd }}$ & 222.20 & 185.50 & 16.20 & 5.60 & 171.30 & 62.40 & 26.40 & 11.40 \\
\hline $\operatorname{March}, 4^{\text {th }}$ & 108.10 & 84.00 & 11.10 & 5.00 & 232.00 & 191.40 & 19.80 & 10.80 \\
\hline $14^{\text {th }}$ & 78.90 & 63.50 & 5.90 & 1.90 & 169.00 & 79.00 & 26.60 & 9.20 \\
\hline $24^{\text {th }}$ & 35.10 & 21.10 & 7.20 & 3.90 & 72.40 & 41.00 & 13.40 & 5.60 \\
\hline April, $3^{\text {rd }}$ & 39.60 & 9.70 & 3.10 & 1.90 & 28.80 & 12.70 & 7.00 & 2.00 \\
\hline $13^{\text {th }}$ & 19.80 & 3.20 & 0.10 & 0.80 & 10.90 & 5.90 & 2.60 & 0.10 \\
\hline Mean & $82.94^{\mathrm{a}}$ & $63.10^{\mathrm{b}}$ & $11.12^{\mathrm{a}}$ & $7.94^{\mathrm{b}}$ & $62.91^{\mathrm{a}}$ & $40.93^{\mathrm{b}}$ & $11.71^{\mathrm{a}}$ & $5.79^{\mathrm{b}}$ \\
\hline L.S.D & \multicolumn{2}{|c|}{11.87} & \multicolumn{2}{|c|}{2.91} & \multicolumn{2}{|c|}{12.78} & \multicolumn{2}{|c|}{16.79} \\
\hline
\end{tabular}

2: Effect of plant stages on the population density of Thrips tabaci on garlic cultivars.

Data in Table (2) show the relationship between T.tabaci population density and three plant stages of the two tested garlic cultivars (first from 1-60 days after transplanting), the second from 60- 120 days later and the last one from 120 till the end of season (harvesting time). The obtained results were as follows:

Fayoum J. Agric. Res. \& Dev., Vol.24, No.1, January, 2010 
Hussein, S.H.A.; et al.

Table (2): Effect of certain climatic factors and plant age on the population density of Thrips tabaci on two garlic cultivars throughout two successive seasons, 2006-2007and 2007-2008 at Beni-Suef district.

\begin{tabular}{|c|c|c|c|c|c|c|c|c|c|c|}
\hline \multicolumn{11}{|c|}{ 2006-2007 season } \\
\hline \multicolumn{11}{|c|}{ Nymphs } \\
\hline \multirow[b]{2}{*}{ Cultivar } & \multirow{2}{*}{$\begin{array}{c}\text { Mean } \\
\text { numbers }\end{array}$} & \multicolumn{4}{|c|}{ Plant age } & \multicolumn{4}{|c|}{ Climatic factors } & \multirow[b]{2}{*}{ C.D3 } \\
\hline & & $1^{\text {st }}$ & $2^{\text {nd }}$ & $3^{\text {rd }}$ & C.D1 & Max. T. & Min. T. & $\begin{array}{c}\text { Mean } \\
\text { R.H. }\end{array}$ & C.D2. & \\
\hline Balady & 82.94 & 0.31 & 0.14 & 0.02 & 60.97 & $-0.75 *$ & $-0.82 * *$ & 0.23 & 68.55 & 76.54 \\
\hline Chinese & 63.70 & 0.23 & 0.04 & -0.1 & $74.00^{*}$ & $-0.71 *$ & $-0.80 * *$ & 0.20 & 63.80 & 76.50 \\
\hline \multicolumn{11}{|c|}{ Adults } \\
\hline Balady & 11.12 & 0.09 & -0.12 & -0.25 & $77.56^{*}$ & $-0.85-* *$ & $-0.88 * *$ & 0.39 & 78.97 & 83.08 \\
\hline Chinese & 7.94 & -0.05 & -0.21 & -0.30 & 48.13 & $-0.76^{*}$ & $-0.72 *$ & $0.61 *$ & 71.86 & 80.01 \\
\hline \multicolumn{11}{|c|}{ 2007-2008 season } \\
\hline \multicolumn{11}{|c|}{ Nymphs } \\
\hline Balady & 62.91 & 0.52 & 0.42 & 0.30 & $75.21 *$ & -0.28 & -0.17 & 0.36 & 49.14 & 85.23 \\
\hline Chinese & 40.93 & 0.43 & 0.32 & 0.20 & 60.08 & -0.31 & -0.21 & 0.46 & 48.30 & 73.53 \\
\hline \multicolumn{11}{|c|}{ Adults } \\
\hline Balady & 11.71 & 0.52 & 0.36 & 0.22 & $86.93 * *$ & -0.44 & -0.33 & 0.43 & 59.35 & 89.27 \\
\hline Chinese & 5.79 & 0.39 & 0.20 & 0.04 & $92.99 * *$ & $-0.63 *$ & -0.54 & $0.56^{*}$ & 65.95 & 94.44 \\
\hline
\end{tabular}

C.D.: Correlation coefficient of determination percentage.

\section{1:T. tabaci nymphs}

In the first season, simple correlation values between mean numbers of T. tabaci nymphs on the leaves of two studied cultivars (Balady and Chinese) and the three periods of plant stages were positive in garlic Balady cultivar, as the simple correlations (r) values were $0.31,0.14$ and 0.02 for the three period of plant stages, respectively. In case of Chinese cultivar the relationship between mean number of $T$. tabaci and plant stages were positive associated with the first and second ages $(r=0.23$ and 0.04 , respectively), while the third plant stages showed a negative effect $(r=-0.1)$.

In the second season, it was clear that the population density of T. tabaci nymphs correlated insignificantly positive with the three tested plant stages, as the corresponding $(\mathrm{r})$ values were $0.52,0.42, \& 0.30$ for balady cultivar and $0.43,0.32 \& 0.20$ for Chinese cultivar. The amount of correlation coefficient of determination (C.D.) by the three plant stages together were 75.21 and $60.08 \%$, respectively.

\section{2:T. tabaci adults.}

In the first season, the obtained data in Table (2) revealed that the infestation rate of T.tabaci adult in Balady cultivar was insignificantly negative correlated with second and third plant stages, as the calculated (r) values were -0.12 and -0.25 , respectively, on the other extreme, insignificant positive relationship was detected in case of the first plant stage, as (r) value was 0.09. For Chinese cultivar, these relationships were insignificantly negative for the three tested plant stages, as (r) values were $-0.05,-0.21$ and 0.30 , respectively.

In the second season, the calculated correlation coefficient value (r) showed that the relationship between the three plant stages and the infestation of T.tabaci was insignificantly positive for both two studied verities. The (r)

Fayoum J. Agric. Res. \& Dev., Vol.24, No.1, January, 2010 
values were $0.52,0.36$ and 0.22 for Balady cultivar and $0.39,0.20 \& 0.04$ for Chinese cultivar, respectively.

The combined effect of the three tested plant stages on the infestation of T.tabaci could be also detected through the calculated (C.D.), these values were 77.56 and 86.93 for Balady cultivar and 48.13 \& 92.99 for Chinese cultivar in the two seasons, respectively.

These results are harmony with the obtained results by Schwartz (1988), who indicated that the young vegetative shoots of grape plants which appeared during spring were the first to be populated by $T$. tabaci but the maximum infestation were recorded during flowering stage. Hanafy (2007) in Egypt showed that the heaviest infestation rate of T.tabaci obtained from sweet pea plants during flowering stage compared with seedling one.

\section{3: Effect of climatic factors on the infestation rate of T.tabaci infesting two garlic cultivars.}

3.1:T. tabaci nymphs.

In the first season, a highly significant negative relationship between the daily minimum temperature and the nymphs infestation was detected for both cultivars, Balady and Chinese and the calculated simple correlations (r) values for these relation were $(-0.82 * *$ and $-0.80 * *$, respectively). While, a significant negative relationship were recorded for maximum temperature $(\mathrm{r}=$ $0.75^{*}$ and $-0.71^{*}$ for both cultivars, respectively). On the contrary, the relationship between mean relative humidity and T.tabaci nymphs was insignificantly positive for the two tested cultivars $(r=0.23$ and 0.20 , respectively).

The combined effect of minimum and maximum temperature \& mean of relative humidity altogether on the infestation of T.tabaci nymphs was recorded, as the values of C.D2. were 68.55 and $63.8 \%$ for Balady and Chinese cultivars, respectively.

The correlation coefficient of determination percentage (C.D3) by the three tested factors (plant stages and climatic factors) were 76.54 and 76.50 for Balady and Chinese cultivars, respectively. This means that there were other inconsiderable factors affecting the build up of T.tabaci population.

In the second season (2007-2008), results showed insignificant negative relationship between maximum and minimum temperature on T.tabaci population for Balady cultivar (-0.28 and -0.17) and for Chinese cultivar $(-0.31$ and -0.21$)$. On the other hand, it was insignificantly positive effect between mean of relative humidity and T.tabaci population, as (r) value of Balady cultivar was 0.36 and Chinese was 0.46 , respectively

The effects of the combined two weather factors altogether (C.D2) were 49.14 and 48.3 for two studied cultivars, respectively.

The amount of (C.D3) by all studied factors together were 85.23 and $73.53 \%$ for Balady and Chinese cultivars, respectively, this indicated that there were another unstudied factors affecting on T.tabaci nymphs population.

\section{2:T. tabaci adults.}

In the first season, the obtained results showed that a highly significant negative relationship between maximum \& minimum temperatures and $T$. tabaci adults population, as $(\mathrm{r})$ values were $\left(-0.85^{* *}\right.$ and $\left.-0.88^{* *}\right)$ and $\left(-0.76^{*}\right.$ and $-0.72 *)$ for Balady and Chinese cultivars, respectively. Meanwhile, the relationship between $T$. tabaci adults infestation and mean of relative humidity

Fayoum J. Agric. Res. \& Dev., Vol.24, No.1, January, 2010 
was insignificantly positive in case of Balady cultivar (0.39) and significant with Chinese cultivar $(0.61 *)$.

The calculated (C.D 2\%) of the three tested climatic factors together were 78.97 and $71.86 \%$ for the two tested cultivars, respectively.

For the combined effect of the all tested factors (plant stages and climatic factors), the results indicated that there were other factors affecting the activity of T. tabaci adults population, as C.D3\% values were 83.08 and 80.01 for Balady and Chinese cultivars, respectively.

In the second season, the effect of the three climatic factors was significantly in case of Chinese cultivar. This relation was negative with maximum \& minimum temperatures, while it was positive with mean of relative humidity, the $(\mathrm{r})$ values were $-0.63^{*},-0.54^{*}$ and $0.56^{*}$ for the three factors, respectively. On the other hand, the population density of T.tabaci adults associated negatively with maximum \& minimum temperatures for Balady cultivar ( $\mathrm{r}=-0.44$ and -0.33 , respectively) and it was positive associated with mean of relative humidity $(0.43)$.

The combined effect of the three tested climatic factors altogether were 59.35 and $65.95 \%$ for Balady and Chinese cultivars, respectively.

Concerning the percentage of (C.D3\%), it could be emphases that the plant stages and weather factors rolled distinct effect on the rate of T.tabaci adults infestation. These values were 89.27 and $94.44 \%$ for both studied cultivars, respectively.

The obtained results are agree with David and Mark (2002) they indicated that there were negative relationship between minimum temperature and infestation of T.tabaci. Tantawy (2006) found that the effect of two weather factors (minimum and maximum temperatures and relative humidity) were insignificantly negative on the population density of $T$. tabaci on sweetpea leave.

\section{REFERENCES}

Daiber, K.C. (1996): Injurious insects, mites and nematodes on various vegetables in southern Africa. Zeitschrift fur pflanzenkrankheiten und pflanzenschutz; 103(3):325-332.

David, A.S. and Mark, D.E.F. (2002): Temperature and the development rates of thrips: Evidence for constraint on local adaptation. Eur. J. Entomo., 99:399-404.

Duchovskiene, L. (2006): The abundance and population dynamics of onion thrips (Thrips tabaci Lind.) in leek under field conditions. Agronomy Research, 4 (Special issue), 163-166.

Hamdy, M.K. and M. Salem (1994): The effect of plantation dates of onion, temperature and relative humidity on the population density of onion thrips, Thrips tabaci Lind. in Egypt. Annals Agric Sci., Ain Shams Univ.39 (1): 417-424.

Hanafy, A.R.I. (2007): effect of certain climatic factors and plant age on the level of infestation with cotton and onion thrips, thrips tabaci Lind. on sweetpea plants in different planting dates. Egypt J. Agric. Res.,85 (6): 2051-2063.

Maha A.M. Tantawy (2006): Certain approaches to ontrol the key pests infesting some sweetpea cultivars. Ph.D. Thesis, Fac. Agric. Ain shams Univ. 261pp.

Fayoum J. Agric. Res. \& Dev., Vol.24, No.1, January, 2010 
Mo, J.; M. Stevens and D.L. Liu (2009): A temperature driven daily process model for onion thrips population in onions. $18^{\text {th }}$ World IMACS/ MODSIM Congress, Cairns, Australia 13-17 July. 554- 560

Sakr, M.M.M. (1996): Efficiency of clonal selection in Egypt and Chinese garlic cultivars. Ms.C. Thesis, Faculty of Agric. Alexandria Univ.

SAS Institute (1988): SAS/Stat user's guide, 6.03 ed SAS institute, Cary, NC.

Schwartz, A. (1988): Population dynamics of Thrips tabaci Lindman (Thysanoptera: Thripidae) on Table Graps. S. Afr. J. Enol. Vitic., 9 (1) :19-21.

Tindall, H.D. (1983): Vegetables in the tropics. (A text book). M. Macmillan press, London, U.K.

Vierbergen, L. M. (1990): The tobacco thrips, Thrips tabaci Lind. and tomato spotted wilt virus in the Netherlands. Gewasbescherming, 21 (6): 159164.

Yamagucchi, M. (1983): world vegetables principles, production and nutritive values. AVI, Westport, conn. (C.F), Hort. Science, 29 (11): 1314-1317.

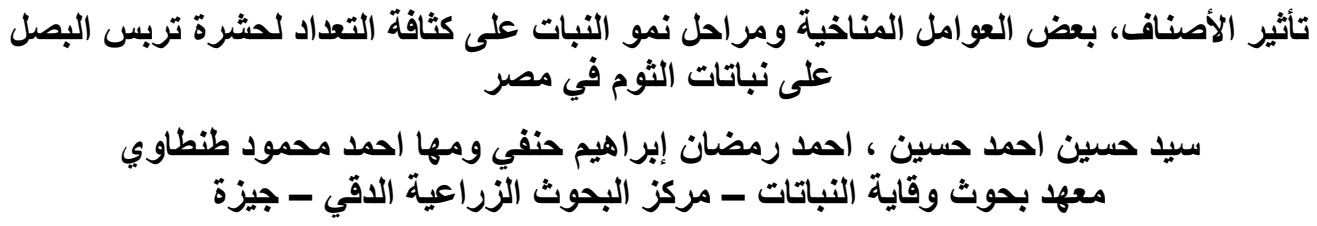

